\title{
The impact of national and international debate in Albania on the jurisdiction of the International Criminal Court
}

\author{
Dr. Florian Bjanku \\ University of Shkodra "Luigj Gurakuqi" \\ bjanku@gmail.com \\ Dr. Yllka Rupa \\ University of Shkodra "Luigj Gurakuqi" \\ yllka_rupa@yahoo.com
}

DOI:10.5901/mjss.2014.v5n19p280

\begin{abstract}
ICC has international legal personality, also it will exercise its legal capacity as much as is necessary to perform its functions and purposes. Despite the support and willingness of many countries to accept and cooperate with the ICC, there are numerous countries that do not accept an institution such innovative product of international law. Although that the European Union hold a unique position to support the ICC, the U.S. holds an opinion contrary, reject it and has attracted signing that made Rome Statute on 31 December 2000. U.S. not only have not accepted the Statute of the ICC, but at the same time to protect especially their armed forces to respond to different countries that have committed crimes falling within the jurisdiction of the ICC, have signed bilateral agreements with specific countries, so that U.S. citizens are not subject to the jurisdiction of the ICC, but the jurisdiction of the United States. Albania is one of the states that has approved the agreement with the United States regarding the jurisdiction of this court. It commits Albania not to deliver or transfer an officer, employee, military personnel or U.S. citizens to the Criminal Court without the consent of the U.S. government. This arrangement is highly regarded by the United States, while the representatives of the European Union there have been criticisms of the decision of Albania. From this the wider debate on the jurisdiction of the ICC, we conclude that the States Parties and the Court must in a foreseeable future to develop a new system of best effective cooperation in criminal practices : direct, flexible, free of bureaucracy unnecessary, with a rapid flow of information and support measures. This system should take into account that the ICC can only be as strong as allowing by States Parties.
\end{abstract}

Keywords: International Criminal Law, Universal jurisdiction, Human rights, Sovereignty, War crimes

\section{Introduction}

Obstacles that come in the direction of creating ICC are generally the result of penetration of realistic theories in international relations. Representatives of this theory does not accept the possibility of being the universal moral standards and emphasize that the international community can't be guided by this "universal morality", but direct interest of the states. Allen Buchanan, researcher on realistic theory that explains, that "under realistic theory, the structure of international relations inhibits the action of morality, except in the case when they coincide with the interests of the state" (Allen Buchanan "From Nuremberg to Kosovo the morality of illegal international legal reform," p. 127(2001) Thus, realists accept that the provision of global justice is a duty of the state and not a task of the international community.

With all the support and willingness of many countries to accept and cooperate with ICC, are many states that do not recognize such an innovative institution, the product of international law. Such a thing was noticed that the Diplomatic Conference, the United Nations representatives to create ICC, when countries such as the United States of America, India, China etc., appear open that were not in favor of establishment of a permanent International Criminal Court. Refusals of ICC was made by quite powerful countries like the U.S., Russia, China or India that represent about half the population of the world or even from countries in which there have been acts punishable under ICC jurisdiction, like as Iraq Israel etc, make very difficult ICC intention to extend jurisdiction over all citizens who have committed crimes such as genocide, war crimes and crimes humanity everywhere and it fail to be followed by the states that would normally exercise jurisdiction over these crimes. 
At a time when European Union countries hold a unique position to support ICC, U.S. holds the opposite view to reject it, and some time ago the U.S. has attracted the signing was made with Rome Statute 31 December 2000. This has occurred many debates between them. So the European Union on May 13 expressed its statement position about Bush administrations' critical regarding for their policy towards creating ICC, and said "The European Union emphasizes that this action may have unwanted consequences in multilateral treaties and mainly for international law and relations. "We attempt to reduce this debate, the Secretary of Defense to the United States, Donald Rumsfeld, stated "The U.S. respects the decision of those countries that have chosen to join the ICC; but at the same time they must respect our decision not supposed to join ICC".

\section{International debate}

U.S. not only have not accepted the Statute of ICC, but at the same time to protect especially their armed forces to intervene in different countries, which are also often accused of states that have committed different crimes falling within the jurisdiction of ICC, have signed bilateral agreements with specific countries, so that American citizens are not subject to the jurisdiction of ICC, but to the U.S. jurisdictions. Such agreements U.S. bases in Article 98 of the Statute, paragraph 2, which provide that: " The Court may not proceed with a request for surrender or assistance which would require the requested State to act inconsistently with its obligations under international law with respect to the State or diplomatic immunity of a person or property of a third State, unless the Court can first obtain the cooperation of that third State for the waiver of the immunity. ".

But the interpretation made by the U.S. government on the one hand, and interpretations made by the countries of the European Union and the working group for drafting the Statute on the other hand, in conjunction with Article 98 of the Statute of ICC is completely in opposite attitudes because EU did not agree that the U.S. have the right to sign bilateral agreements ranging from interpreting Article 98 of the Statute. However, in this case ICC would be itself the final judge to decide on the legality of agreements stemming from Article 98 of the Statute, according to article 198 (1) of the Code of Procedures. Obviously, based on the principle of the Statute of Rome that "no one can stand above the law and immune when conducting serious crimes as genocide, crimes against humanity and war crimes "

In this way, the U.S. represents a realistic theory, in that, ensuring that global justice is the duty of states and international institutions not. According to Henry Kissinger, a strong representative of realistic theory and ex-Secretary of State of the United States, there are four basic reasons regarding rejection that make the U.S. International Criminal Court:

Accepting ICC "creates significant changes in the practice of U.S. constitutional". In this way, Kissinger states that if ICC Office shall exercise jurisdiction over this will GONT Americans in violation of the U.S. constitution that (Henry Kissinger, "The Pitfalls Jurisdiction for Universal," Foreign Affairs" (2001).Kissinger notes that, ICC does not provide that judicial proceeding can be fair and equitable for reasons of its potential politicization. 1

Kissinger argues that states should be allowed to resolve conflicts within their territory, so he says, "it is possible to pursue and convict criminals in that country's courts which are competent to adjudicate this case in accordance with the stability and willingness of democratic institutions "(Henry Kissinger, "The Pitfalls Jurisdiction for Universal," Foreign Affairs" (2001).

Kissinger considers as "extraordinary efforts ICC to exercise its jurisdiction over Americans even though the United States does not participate in this treaty"

Contrary to the reasons that represents Kissinger regarding the rejection of ICC-by the United States, Kenneth Roth, international law scholar and executive director of "Human Rights Watch", states:

First, with respect to the problem that presented Kissinger, for violation of the U.S. Constitution that if accepted will ICC Office. Roth contradict the fact that "an American who commits crimes such as genocide, war crimes and crimes against humanity on American territory and American authorities will not pursue these crimes; This would be a signal of a constitutional crisis many times heavier than the pursuit of such cases by the ICC. (Kenneth Roth, "The case of universal jurisdiction," Foreign Affairs (2001).

Secondly, regarding the reasoning ICC Kissinger has not possibility to provide a fair and equitable judicial proceeding because of its potential politicization. Roth's opposition to the fact that "Experiences of the ad hoc International Criminal 
Tribunal for Yugoslavia and Rwanda, demonstrating that international lawyers when they have been forced to decide the fate of a suspect, it had been done in full compliance with the standards of a court fair and equitable "

Thirdly, regarding to the argument that Kissinger is possible to pursue and convict criminals in domestic courts that are competent to adjudicate these cases, the Roth contradict the fact that "national solution" fail, when systems "democratic" not are unwilling or are unable to prosecute crimes of genocide, crimes against humanity or war crimes, especially in those cases where heads of states are involved. (Henry Kissinger, "The Pitfalls Jurisdiction for Universal," Foreign Affairs" (2001).

Fourth, regarding the fact that Kissinger presented regarding the extraordinary efforts that ICC-to exert its jurisdiction over Americans even though the United States has not accepted it. Roth argued that "the U.S. itself exercise such jurisdiction over other citizens when pursuing terrorists or drug traffickers ... without the consent of the government of the suspect" (Kenneth Roth, "The case of universal jurisdiction," Foreign Affairs (2001).

These are some of the arguments and counter-arguments that generally arise from supporters and opponents regarding rejection of ICC especially by U.S. Arguments such as those presented about the rejection of the US-ICC more or less are presented by other countries that do not accept ICC. What unites all countries which are against ICC jurisdiction is a problem of infringement of sovereignty, which will treat below.

\section{The positioning of Albania}

Albania was one of 160 countries that participated in the "Diplomatic Conference of Representatives of the United Nations for the establishment of the International Criminal Court", held on 15 June to 17 July 1998 in Rome, and at the same time by signing the Rome Statute for ICC creating that.

On 8 May 2002 the Prime Minister of that time, Pandeli Majko order creating the conditions for the ratification of the Statute, made a request to the Constitutional Court with the subject: "Compliance of "Rome Statute of the International Criminal Court " with the Constitution of the Republic of Albania. This procedure provided by the Constitution itself in Article 135, item $b$, which states that the Constitutional Court decides on the "compatibility of international agreements with the Constitution of Albania". The signing of the Rome Statute by Albania, as for most of the signatory countries, there was much debate and discussion on the problematic extension of jurisdiction ICC, linking this directly with the constitutional principle of sovereignty internal. Problems such as the precise scope of jurisdiction ICC in relation to national courts, the inclusion within the jurisdiction of the Court and the high official person who has immunity under the Constitution or of this International Court being outside constitutional sanction that determines the national courts may exercise judicial power, require a cautious interpretation and detailed by the Constitutional Court. Through the Constitutional Court decision no. 186, dated 23.09.2002, decided that "the Statute of the International Criminal Court, established by the Treaty of Rome is in accordance with the Constitution of the Republic of Albania". Reasoning that made this decision after the Constitutional Court made a brief ICC-operation that focused on three main points and most controversial of conformity with the Constitution of Albania:

We respect ICC jurisdiction in relation to constitutional concepts of sovereignty, Constitutional Court begins its case by context the Preamble of the Constitution of Albania which accepts as the highest values of humanity justice, peace, and cooperation through nations shall also analyzes the Article 2 of the Constitution stipulates that "... peace and national interests of the Republic of Albania can participate in a system of collective security, based on a law approved by a majority of all members of Parliament. In the analysis of these provisions Constitutional Court qualifies as provisions containing these basic principles adapted to new realities, which Albania has long recognizes "de facto" and who are one of the "most powerful integrative elements and can not be seen denial of the sovereignty of the people. "Constitutional Court based on this reasoning and in Article 122 of the Constitution which states that international agreements ratified by the Republic of Albania constitute part in the internal legal order.

The Constitutional Court further analyzes ICC judicial jurisdiction in relation to Article 135 paragraph 1 of the Constitution which provides that "The judicial power is exercised by the Supreme Court and courts of first instance, which are established by law" and the second paragraph of that article in which sanctioned "Parliament may establish by law a court for specific areas, but in any case the court is extraordinary.". Referring to reports of sovereignty by accepting ICC jurisdiction and Article 123 of the Constitution where Paragraph 1 provides that "The Republic of Albania, on the basis of international agreements, delegates to international organizations for constitutional questions to the state powers certain " At this point the Constitutional Court interprets the basis of constitutional spirit, but used to express more clearly according to international constitutional jurisprudence "transfer of rights of sovereignty has limits there, where constitutional identity 
begins to be questioned". Having completed this interpretation Constitutional Court sees no excess of these limits to transfer of some powers to the judiciary in a given international interest proceed the authors of crimes of genocide, crimes against humanity, war crimes and aggression. Arriving, so we conclude that the activity and its functions do not affect the constitutional provisions regarding the exercise of sovereignty.

In connection with immunity in criminal process Constitutional Court analyzes the constitutional provisions which have provided immunity from criminal proceeding integrate as part of legal status on a number of subjects, ranging from the head of state, parliamentarians, members of government, etc., in Statute of ICC Article 27 of the Statute states: " This Statute shall apply equally to all persons without any distinction based on official capacity. In particular, official capacity as a Head of State or Government, a member of a Government or parliament, an elected representative or a government official shall in no case exempt a person from criminal responsibility under this Statute, nor shall it, in and of itself, constitute a ground for reduction of sentence".

By analyzing the above provision in relation to Article 123 of the Albanian Constitution (devolving powers to international organizations for constitutional questions to certain state) Constitutional Court recognizes that internal arrangements for immunity does not inhibit the transfer of jurisdiction to ICC Office. This is due to the immunity of the judiciary serves domestic and defense front that it stems from the principle of separation and balance of powers guaranteed by Constitution. In this sense, the Constitutional Court also stated that according to the Constitution principles of international law generally accepted are part of domestic law, then the lack of immunity in international criminal proceed certain crimes high risk becomes part of the Albanian legal system. In this regard the Constitutional Court jurisprudence recognizes that $\S$ has developed a series of steady habits main goal was initiated by the authors of these criminal acts to be removed possibility considered protected by acts committed in the exercise of power (Acte iure imperii)

As a conclusion of this reasoning the Constitutional Court stated that the statute does not come in conflict with constitutional provisions regarding the immunity of the head of state and a variety of other subjects because the immunity of these entities belonging to national jurisdictions. As a result, it can not stop an international institution as ICC to exercise its jurisdiction over persons of this category, who have committed crimes envisaged by the Rome Statute.

In connection with the constitutional principle of "ne bis in idem" (not punishment twice for the same crime) of the Rome Statute. Court examines Article 20 of the Statute which this principle in which there are two aspects, namely, that the implementation of this principle in trials within ICC and in what relates to the judgments of other courts . If the first aspect of the statute clearly states that ICC has not retry a person for an offense for which he is being tried by ICC Office. The second problem is the aspect under which the statute has accepted the rule according to which ICC has become competent to judge a person for the offense for which he was investigated and adjudicated by the courts only when it becomes necessary and for this anticipated event are two cases when the local judiciary acts (a) Were for the purpose of shielding the person concerned from criminal responsibility for crimes within the jurisdiction of the Court; or (b) Otherwise were not conducted independently or impartially in accordance with the norms of due process recognized by international law and were conducted in a manner which, in the circumstances, was inconsistent with an intent to bring the person concerned to justice. This was a delicate problem to be discussed and interpreted by the Albanian Constitutional Court in relation to the constitutional principle of impunity twice provided by Article 34 of the Constitution in the Chapter on Rights and Fundamental Freedoms, which states that: "No one can be punished more than once for the same offense, nor tried again, except when it is determined by a case in higher court, in the manner prescribed by law " Constitutional Court faced the provisions under Article 20 of the Statute of ICC-than (ne bis in idem) with Article 34 of the Constitution (IMPUNITY twice), says that addressing issues of ICC has, under Article 20, paragraph 3, the letters "e", "a" and "b", was the nature of a review under section 34 of the Constitution has the power higher court. The Constitutional Court further stated that Article 34 of the Constitution did not consider the institution of the Supreme Court, but the high court, according to a certain order. So ICC has actually appears as the highest court (about the trial of certain crimes within its jurisdiction).

Having completed this reasoning the Constitutional Court stated that, according to the preamble of the Rome Statute, ICC has presented as additional court of national jurisdiction (the principle of complementarity). In cases showing that the internal judicial authority has not developed a real proceeding (considered null), put into motion ICC as a higher court. Thus, the Constitutional Court concluded that these provisions do not conflict with each other, it concludes. Parliament of Albania, after all conditions were created with the signing of the Constitutional Court, and the decision regarding compliance with the Constitution of the Republic of Albania to the Rome Statute for ICC-in, and made the last step by ratifying the Statute Law 8984, dated 12/23/2002, and thus making the internal part of the normative system, even now it can be said that has superiority with domestic laws. Also evidenced by this action in order to respect the general principles of international law embodied in the Statute of ICC and in the Albania Constitution. It is understood that the ratification of the 
Statute need to take into account the history of conflict in the Balkans region, the consequences of which are still present. Through this ratification enriched spirit, leadership and constitutional traditions of the country through the opening and managing of legislation and judicial practices, versus international ones.

However, there was plenty of debate that Albania has signed agreement with U.S. A at about U.S. citizens do not surrender the International Criminal Court, based on Article 98 of the Rome Statute. This agreement was signed on May 2, 2003, between U.S. Secretary of Defense, Colin Powell, and Prime Minister of Albania, Fatos Nano, was criticized by the European Union. Thus, the High Commissioner of the EU, Patten stated that: "Such agreements are not consistent with our principles which we have previously determined and related to the International Criminal Court" Is also expressed the opinion that this agreement may affect Albania can view the EU accession Although the under Patten statement that: "We are not of those who threaten our partner. Others may act in that way. We did not do so and will continue to move forward, but simply are disappointed by this action of Albania ", it seems that at least "de jure " agreement will not affect this accession.

\section{Final remarks}

The problem actually debated regarding Sovereignty and the International Criminal Court in are presented in a summary in the form of questions:

Is ICC Statute a legal authority over all national laws, including the basic laws of a state, is pro constitution, violating the sovereignty of the States?

Is creating ICC an attempt by the United Nations to create a sweeping powers above the United vegante limiting their internal sovereignty?

Jurisdiction of ICC violates State Sovereignty in some cases and individuals, even though the States of the are not an integral part of the statute?

A charter aims to force States before they decide to accept it?

A court is a politicized institution that could be used against states or individuals and can't ensure a fair, impartial and independent judicial proceeding?

Regarding the first question that arises, it can be said that the Statute of ICC is an international treaty that can be incorporated into domestic law only in case of ratification by the States. Regarding what statute attribute to the Court superiority over national law. The statute gives the court the right to act only when the crimes under its jurisdiction not prosecuted by national authorities, based on the principle of complementarity. So this Statute defines the priority for the prosecution of crimes belongs to the National Court without prejudice Sovereignty.

Regarding the second question, under statute or court or Assembly of States Parties, which together constitute ICC are not the United Nations body. Although negotiations for the creation of ICC took place in United Nations forums, it will be independent of the UN. ICC shall be directed to the States that have chosen to ratify its statute. Its relationship with the United Nations will adjusted through an agreement which is expected to be reached soon.

The problem in relation to the third, the Statute provides that the Court will exercise its jurisdiction over the crimes that take place in a state that is party to the Statute, regardless of who holds the citizenship of the person who committed the crime. This arrangement is universally known in terms of the domestic law of the states. In this way the states according to their national legislation have the right to judge foreigners who commit crimes within their territory, or have the right to extradite persons accused of committing crimes captured in their territory who are required by another state. This is an inherent right of sovereign States which may work well for ICC, without prejudice Sovereignty.

Regarding the fourth problem can be stated that the Statute, as every international treaty, does not assign any obligation for states that are not party to this treaty, nor bring any consequence on them. The Court has jurisdiction only over individuals, rather than governments, so U.S. sovereignty remains intact.

In connection with the last question that arises, it can be said that ICC can not be politicized while no state has a role to other States members, because for each State has only one representative and one vote only in Assembly of States Parties which apart this, for making decisions required at least a simple majority vote of the States Parties, and essentially important for decisions require a majority of two thirds of the votes of the Assembly. So, in terms of selection of judges required a two-thirds majority of the Assembly and that judges should belong to different states and through them to ensure a 
representation of the world's leading systems, representation of geographic entitlements and fair representation of Judges feminine and masculine. In this way the Court can provide a fair, independent and non-political independent judicial proceeding.

From this the wider debate on the jurisdiction of the ICC, we conclude that the States Parties and the Court must in a foreseeable future to develop a new system of best effective cooperation in criminal practices : direct, flexible, free of bureaucracy unnecessary, with a rapid flow of information and support measures. This system should take into account that the ICC can only be as strong as allowing by States Parties.

\section{REFERENCES}

Bassiouni, MC. Introduction to international criminal law. New York: Transnational Publishers; 2003

Buchanan , Allen (v. 3, no. 4, july 2001) "The morality of illegal international legal reform. from Kosovo to Nuremberg "

Grossman, Marc (accessed April 6, 2004) "American Foreign Policy and the International Criminal Court," Remarks to the Center for Strategic and International Studies, U.S. Department of State, May 6, 2002, <www.state.gov/p/9949.htm> (accessed April 6, 2004)

Haug, Hans -(bern, stuttgart, vienna 1993) "The international red cross and crescent movement; humanity for all "

Kissinger , Henry (volume 80, no. 4; august 2001) The international red cross and crescent movement - humanity for all "

Sadat, Leila Nadya The International Criminal Court and the Transformation of International Law: Justice for the New Millennium (Ardsley, New York: TransnationalPublishers, 2002);

Roth Kenneth ," Foreign affairs (sep-oct 2001) "The case of universal jurisdiction"

William A. Schabas, An Introduction to the International Criminal Court (Cambridge University Press, 2001). 